\title{
FAILED EXPERIMENT: TWOMBLY, IQBAL, AND WHY BROAD Pretrial Discovery SHOUld Be FurTher Eliminated
}

\author{
George ShePherd*
}

The provisions for broad discovery in the 1938 Federal Rules of Civil Procedure were a revolutionary experiment. The experiment began to fail from the beginning and has continued to fail. It has dramatically increased litigation's cost and pain, with few balancing benefits. Moreover, it has caused the profession to switch to hourly billing, causing an additional array of harms. Broad discovery should be eliminated, returning the United States to the sensible approach of the rest of the world. In Twombly and Iqbal, the Supreme Court went part of the way towards doing exactly that. Although the decisions nominally addressed issues of pleading, their focus was on the flaws in the discovery process, and the decisions eliminate discovery in many cases. The decisions moved in the right direction, but did not go far enough. Instead, broad discovery should be eliminated for all cases.

\section{INTRODUCTION}

The discovery provisions in the 1938 Federal Rules of Civil Procedure ("FRCP"), and thereafter in most states' procedural codes, were a grand experiment. But the last seven decades have shown that, even by the FRCP's own standards, they are a failure. They have not led to the "just, speedy, and inexpensive determination of every action," as Rule 1 promised. ${ }^{1}$

Instead, discovery is avoided in most cases and ruins many of the rest. Most litigants choose to make their cases discovery-free, finding the process unnecessary, unhelpful, and even harmful.

In contrast, broad discovery has transformed the most important cases: those with the most at stake, addressing society's most crucial issues and involving the best, highest-paid lawyers. These cases now last longer and cost more to litigate. They settle less, requiring more trials and consuming more judicial resources.

There is no reason to conclude that all of this time and expense leads to more justice. Discovery is a powerful weapon for imposing expense and difficulty on an adversary. Plaintiffs and defendants with frivolous cases often use either discovery, or the threat of it, to defeat justice. Plaintiffs with baseless claims wield discovery to coerce in terrorem settlements. Defendants escape liability by imposing oppressive, intrusive discovery requests.

For the lawyers who do not avoid discovery, discovery has made them wealthy and increased their numbers. Because cases last longer and settle less, more lawyers are needed. Each additional dollar of cost that discovery imposes on litigants is another dollar for a lawyer.

However, broad discovery has otherwise deeply harmed the practice of law.

* Professor of Law, Emory University School of Law. I thank Morgan Cloud, Rich Freer, and seminar participants at Emory University School of Law and George Washington University Law School for helpful comments.

1. FED. R. CIV. P. 1.

http://dx.doi.org/18060/4806.0072 
Some lawyers' new titles reflect this change. Because "trial lawyers" no longer try cases, they are now called "litigators." Elite lawyers now devote themselves almost completely to discovery and other motions based upon it, such as summary judgment motions. This work, although lucrative, is often boring drudgery.

Moreover, the use of broad discovery caused the profession to switch from fixed-fee billing to hourly billing. Because broad discovery made a case's expected costs uncertain, the use of fixed fees became too risky. After most states followed the federal courts' lead and began permitting broad discovery in the $1940 \mathrm{~s}$ and $1950 \mathrm{~s}$, the profession switched to hourly billing in the 1960s and 1970 s. $^{2}$

Like the discovery rules that caused it, hourly billing may have generally increased lawyers' incomes. ${ }^{3}$ But it has corroded the legal profession in other ways, making many lawyers miserable, despite their wealth. ${ }^{4}$ For example, it has placed many lawyers on a lucrative, but deadening, treadmill in which some lawyers must bill more than 2000 hours per year, often requiring them to spend ten to twelve hours in the office per day, six days per week. ${ }^{5}$ Lawyers no longer have time for pro bono or other public service. ${ }^{6}$ Moreover, hourly billing rewards inefficiency and creates incentives for lawyers to lie to clients. ${ }^{7}$

Broad discovery should be eliminated. It is a seventy-year experiment that has failed. The rest of the world recognizes this; no other country has copied the United States' approach. ${ }^{8}$ Moreover, almost from the beginning, discovery's

2. This Article's discussion of how discovery caused hourly billing is based upon George Shepherd \& Morgan Cloud, Time and Money: Discovery Leads to Hourly Billing, 1999 U. ILL. L. REV. 91.

3. See infra Part II.B.

4. See infra Part II.B.

5. Number of Associate Hours Worked Increases at Largest Firms, NAT'L AsS'N FOR L. Placement (Feb. 2012), http://www.nalp.org/billable_hours_feb2012 [http://perma.cc/A779B286] (noting that across 499 reporting offices, attorneys averaged 1799 billable hours in 2010, with an average of 2044 total hours worked, and $9.7 \%$ of offices reporting require at least 2000 billable hours); see also The Truth About the Billable Hour, YALE L. SCH. CAREER DeV. OfF. (May 2015), http://www.law.yale.edu/studentlife/cdoadvice_truthaboutthebillablehour.htm [http://perma.cc/2LYP-3TT7].

6. Robert Hirshon, Am. Bar Ass'n, ABA Commission on Billable Hours Report ix (2002), available at http://ilta.personifycloud.com/webfiles/productfiles/914311/FMPG4 ABABillableHours2002.pdf [http://perma.cc/R44A-WURK] ("The elimination of discretionary time has taken a toll on pro bono work and our profession's ability to be involved in our communities.").

7. Id. at 5.

8. See Karin Retzer \& Michael Miller, Mind the Gap: U.S. Discovery Demands Versus EU Data Protection, Privacy \& Security Law Report, 10 PrivaCy \& SECURITY L. ReP. 886 (2011), available at $\mathrm{http}: / /$ media.mofo.com/files/Uploads/Images/110601-US-Discovery-Demands-versusEU-Data-Protection.pdf [http://perma.cc/D8D8-H54E] (noting Europe, in particular, takes a skeptical view of the U.S. discovery process, as a direct challenge to individual privacy; The 
flaws have been recognized, with bar committees, scholars, and courts pointing out discovery's harmful effects and proposing changes. ${ }^{9}$ Some of the most recent criticism of discovery came from the Supreme Court through its decisions in Bell Atlantic Corp. v. Twombly ${ }^{10}$ and Ashcroft v. Iqbal. ${ }^{11}$

Although the diagnosis has been correct, the modest treatments that have been continually implemented have achieved little. The cure is simple: broad discovery is a cancer that should be cut out completely.

Both the legal profession and society at large would be better off without broad discovery. The cost of litigation would decline substantially. Cases would settle more frequently and quicker. Parties would no longer be able to use discovery as a weapon to achieve unfair results. Fewer frivolous suits would result in lucrative settlements. Corporate defendants would no longer be able to stonewall by asserting large, intrusive discovery requests.

Although many lawyers might lose their jobs as litigation becomes quicker and easier, the displaced lawyers would be free to pursue careers that contribute more to society's well-being.

Opponents of the cure might argue that, absent broad discovery, plaintiffs would be unable to obtain the defendant's secret internal documents that would be necessary to prove liability. ${ }^{12}$ The decisions in Twombly and Iqbal certainly create this concern because they can require cases to be dismissed before a plaintiff has had the opportunity to conduct discovery.

However, this concern turns out to be of little importance. First, in part because of the 2015 amendments to the FRCPs that narrow discovery's scope, the number of cases in which plaintiffs will successfully obtain such documents is probably small and not worth discovery's large costs. ${ }^{13}$ Second, the number of cases in which discovery's locating secret information permits a plaintiff to win a case is probably outweighed by the number of cases in which defendants' imposition of burdensome discovery requests causes plaintiffs to lose cases, or

European Union adopted the European Privacy Directive and several European states adopted "blocking statutes" with the specific goal of limiting the reach of discovery requests from U.S. courts).

9. See, e.g., Frank H. Easterbrook, Discovery as Abuse, 69 B.U.L. REV. 635 (1989); Gordon W. Netzorg \& Tobin D. Kern, Proportional Discovery: Making It the Norm, Rather than the Exception, 87 DENV. U. L. REV. 513 (2010).

10. 550 U.S. 544 (2007).

11. 556 U.S. 662 (2009).

12. Amendments to the Fed. Rules of Civil Procedure, 85 F.R.D. 521, 523 (1980) (Powell, J., dissenting) (" $[\mathrm{T}]$ he discovery Rules will continue to deny justice to those least able to bear the burdens of delay, escalating legal fees, and rising court costs.").

13. See Fed. R. Civ. P. 26(b)(1). The amendment removes the controversial catch-all phrase, "Relevant information need not be admissible at the trial if the discovery appears reasonably calculated to lead to the discovery of admissible evidence." Id. (emphasis added). As a result, a party may only discover information "relevant to any party's claim or defense and proportional to the needs of the case," and courts will consider "the parties' resources ... and whether the burden or expense of the proposed discovery outweighs its likely benefit." Id. (emphasis added). 
not to file them at all. Third, any problem of defendants' possession of secret documents can also be solved by shifting burdens of proof, as in many countries that prohibit broad discovery. ${ }^{14}$

That broad discovery's elimination would be beneficial is confirmed by the experience in the rest of the world. The proportion of lawyers in the population in places such as western Europe is much smaller and the lawyers generally earn less. ${ }^{15}$ But the lawyers there also work less and appear happier. ${ }^{16}$ A much higher proportion of clients pay fixed fees, rather than hourly fees. ${ }^{17}$

Moreover, the legal systems in many of these countries appear to achieve bottom-line goals better than the U.S. system. For example, one goal of a legal system is to deter manufacturers, drivers, and others from improperly endangering the public. Although many other factors are also at play, many European legal systems appear to achieve this better than the U.S. system. For example, the automobile accidental death rate in Germany is less than half the U.S. rate. ${ }^{18}$

The elimination of broad discovery is not a risky, fringe proposal. Instead, the current U.S. system is the extreme outlier. Eliminating broad discovery would return the United States to the mainstream, with almost every other country. As in other countries, discovery should be strictly limited and allowed only in exceptional circumstances.

The Supreme Court has recently expressed similar concerns about the discovery process and, even more importantly, has eliminated discovery in many cases. $^{19}$ The decisions in Twombly and Iqbal nominally address issues of

14. See infra Part III.

15. See generally Am. Bar Ass'n, ABA National Lawyer Population Survey (2015), available at http://www.americanbar.org/content/dam/aba/administrative/market_research/totalnational-lawyer-population-1878-2015.authcheckdam.pdf[http://perma.cc/7HFB-V99Q]; see also Counsel of BARs \& Law Societies of Eur., Legal Profession: Key Figures of Six Countries OF THE EUROPEAN UNION 8 (Mar. 2013), available at http://www.ccbe.eu/fileadmin/ user_upload/NTCdocument/Statistics_Book_Angl1_1366619056.pdf[http://perma.cc/4FV2-ERUC ] (finding the concentration of attorneys in the United States is approximately five times higher than Spain and seven times higher than Germany).

16. See Org. for Econ. Co-operation \& Dev., Average Annual Hours Actually WORKED PER WORKER (2014) (stating that workers in Germany and Spain worked an average of 1371 and 1689 hours, respectively, in 2014, while U.S. workers worked an average of 1789 hours).

17. See, e.g., Attorney fees under German law: A Courtesy Summary for English Speakers and/or Expats Living in Germany, KRAVETS \& KRAVETS (July 6, 2014), http://www.kravets.de/ kkreport/2014/7/6/attorney-fees-under-german-law-a-courtesy-summary-for-english-speakers-livingin-germany [http://perma.cc/Y8C2-9654] (noting most legal matters are governed by statutory limits under German law).

18. See, e.g., World Health Org., Global Status Report on Road Safety 116, 227 (2013), available at http://www.who.int/violence_injury_prevention/road_safety_status/2013/en/ [perma.cc/JR97-5V2H].

19. See, e.g., Ashcroft v. Iqbal, 556 U.S. 662 (2009); Bell Atl. Corp. v. Twombly, 550 U.S. 544 (2007). 
pleading. ${ }^{20}$ However, like the analysis in this Article, their focus was on the harms of the discovery process. ${ }^{21}$ Moreover, just as this Article proposes, the decisions eliminate discovery in many cases; the decisions require early dismissal of certain cases that might otherwise lead to discovery fishing expeditions.

My proposal safely builds on the Twombly and Iqbal decisions by proposing elimination of broad discovery in all cases, rather than just some. The decisions moved in the right direction, but did not go far enough. Instead, broad discovery should be eliminated completely.

This Article proceeds as follows. Part I discusses the history of discovery and its many harmful impacts. Part I also discusses attempts over many decades to fix the system by tinkering with the discovery rules, as well as making changes judicially, as in Twombly and Iqbal. Part II focuses on one of broad discovery's specific impacts: the rise of hourly billing. Part III describes how eliminating broad discovery would provide many benefits and little harm.

\section{A Grand Experiment Out of Control}

The discovery provisions of the FRCP were an unprecedented experiment. The new discovery rules transformed the practice of law. However, almost immediately, critics began to note the system's basic flaws. A wide array of fixes have been proposed and adopted. ${ }^{22}$ However, these fixes have not worked. Discovery still imposes many harms.

\section{A. A Crusader's Revolutionary New System}

The drafters of the discovery provisions of the FRCP knew that their new system was revolutionary and unprecedented. ${ }^{23}$ That is, they knew that their new system was a grand experiment. Although some state courts offered isolated discovery opportunities, no state combined them together as did the FRCP. Moreover, many of the state provisions that did exist could not take effect because courts held that federal provisions with no discovery occupied the field, precluding application of the state provisions. ${ }^{24}$

The new federal discovery rules were a complete list of all discovery devices that were available in any state and in Great Britain. ${ }^{25}$ As Stephen Subrin noted:

If one adds up all of the types of discovery permitted in individual state

20. See, e.g., Iqbal, 556 U.S. 662; Twombly, 550 U.S. 544.

21. See, e.g., Iqbal, 556 U.S. 662; Twombly, 550 U.S. 544.

22. See, e.g., Easterbrook, supra note 9; Netzorg \& Kern, supra note 9.

23. See Richard L. Marcus, Retooling American Discovery for the Twenty-First Century: Toward a New World Order?, 7 Tul. J. INT'L \& COMP. L. 153, 158-59 (1999) (noting that the new discovery provisions were genuinely unprecedented); Stephen N. Subrin, Fishing Expeditions Allowed: The Historical Background of the 1938 Federal Discovery Rules, 39 B.C. L. REV. 691, 734, 736 (1998) (describing the 1938 "discovery revolution").

24. Marcus, supra note 23, at 159; Subrin, supra note 23, at 698-701.

25. Marcus, supra note 23, at 159; Subrin, supra note 23, at 718. 
courts, one finds some precursors to what later became discovery under the Federal Rules; but . . . no one state allowed the total panoply of devices. Moreover, the Federal Rules, as they became law in 1938, eliminated features of discovery that in some states had curtailed the scope of discovery and the breadth of its use. ${ }^{26}$

The methods now include required initial disclosures, ${ }^{27}$ depositions by oral examination, ${ }^{28}$ depositions by written questions,${ }^{29}$ interrogatories, ${ }^{30}$ production of documents and things, ${ }^{31}$ medical examinations, ${ }^{32}$ and requests for admission. ${ }^{33}$

The approach was revolutionary not only because of the number of discovery devices that were now available, but also because of how easily the devices could be invoked. At the same time, the rules that permitted the discovery devices also permitted what is called "notice pleading." ${ }^{34}$ A plaintiff could file a complaint, survive a motion to dismiss, and be permitted to use the discovery devices by providing a complaint that offered merely "a short and plain statement of the claim showing that the pleader is entitled to relief." ${ }^{35}$ Later courts interpreted this to mean that the complaint could include only the simplest conclusory summary of the plaintiff's differences with the defendants, and needed to include few, if any, facts. The Supreme Court summarized the relaxed pleading standard when it noted the "accepted rule that a complaint should not be dismissed for failure to state a claim unless it appears beyond doubt that the plaintiff can prove no set of facts in support of his claim which would entitle him to relief." ${ }^{36}$ Accordingly, a plaintiff can commence a case with few, or no, facts in hand and instead attempt to gather facts during the discovery process.

The framers knew that their approach was unprecedented. ${ }^{37}$ Moreover, they knew that such broad discovery created dangerous risks of abuse. ${ }^{38}$ However, as the chief reporter for the FRCP, Charles Clark, later noted, the chairman of the Advisory Committee on these provisions, Edson Sunderland, "had developed both the enthusiasm and the drive of a crusader" to have the discovery provisions

26. Subrin, supra note 23 , at 719.

27. FED. R. Civ. P. 26(a)(1).

28. FED. R. CIV. P. 30.

29. FED. R. CIV. P. 31.

30. FED. R. CIV. P. 33.

31. FED. R. CIV. P. 34.

32. FED. R. CIV. P. 35.

33. FED. R. CIV. P. 36.

34. Pleading, Black's Law Dictionary (10th ed. 2014) (“A system of defining and narrowing the issues in a lawsuit whereby the parties file formal documents alleging their respective positions.").

35. Fed. R. CIV. P. 8(a)(2).

36. Conley v. Gibson, 355 U.S. 41, 45-46 (1957).

37. Marcus, supra note 23, at 158-59; Subrin, supra note 23, at 734, 736.

38. Marcus, supra note 23, at 160; Subrin, supra note 23, at 719. 
adopted. ${ }^{39}$ Indeed, Sunderland had for years argued in print that broad discovery should be permitted. ${ }^{40}$ Accordingly, in public hearings on the provisions, the committee did not reveal the provisions' revolutionary nature, instead suggesting that the changes were merely incremental. ${ }^{41}$

Later courts recognized the new rules' revolutionary nature. For example, in the famous Hickman v. Taylor case, the Third Circuit noted in 1945 that "[t]he rules probably go further than any State practice." ${ }^{42}$ Similarly, the FRCP's chief reporter noted, in 1959: "The system thus envisaged ... had no counterpart at the time [Edson Sunderland] proposed it." ${ }^{43}$

Before 1938, federal courts, sounding the same as all countries other than the United States today, denounced as improper "fishing expeditions," any attempt to require disclosure of the adversary's case or evidence. ${ }^{44}$ By 1946, the FRCP revolution had converted these attitudes completely. In the appeal of Hickman v. Taylor, the Supreme Court stated: "No longer can the time-honored cry of 'fishing expedition' serve to preclude a party from inquiring into the facts underlying his or her opponent's case. Mutual knowledge of all the relevant facts gathered by both parties is essential to proper litigation." ${ }^{45}$

\section{B. The New Discovery Rules Transform Litigation}

The new provisions for wide-open discovery created both opportunities and incentives. First, the new rules greatly expanded litigants' opportunities to obtain information from their adversaries. ${ }^{46}$ Second, the new rules created an incentive for lawyers to use discovery, not only to obtain useful information, but also to a gain tactical advantage by imposing large discovery costs on their adversaries. Conducting discovery became expensive, both for the party who sought discovery and for the party who responded to the discovery request. ${ }^{47}$

As lawyers exploited the new opportunities for broad discovery, the discovery process transformed the practice of law. ${ }^{48}$ Maurice Rosenberg, one of the leading experts on the FRCP and litigation procedure, has noted, "No change in litigation practice resulting from the Rules has had as great an impact as the

39. Charles E. Clark, Edson Sunderland and the Federal Rules of Civil Procedure, $58 \mathrm{MICH}$. L. REV. 6, 9 (1959).

40. See generally Edson R. Sunderland, Scope and Method of Discovery Before Trial, 42 YALE L.J. 863 (1933).

41. Marcus, supra note 23, at 160; Subrin, supra note 23, at 725-26.

42. Hickman v. Taylor, 153 F.2d 212, 216 (3d Cir. 1945), aff'd, 329 U.S. 495 (1946).

43. Clark, supra note 39, at 11.

44. See Carpenter v. Winn, 331 U.S. 533, 540 (1911).

45. Hickman v. Taylor, 329 U.S. 495, 507 (1947).

46. See Fed. R. Civ. P. 26-37.

47. See George B. Shepherd, A Theoretical Model of the Pretrial Litigation Process and Discovery (1998) (unpublished manuscript, on file with the author).

48. See generally Maurice Rosenberg,Federal Rules of Civil Procedure in Action: Assessing Their Impact, 137 U. PA. L. REV. 2197 (1989). 
liberalization of pretrial discovery." ${ }^{49}$ Although some cases had little discovery, in a substantial fraction of cases, the use of discovery quickly exploded and, as Rosenberg has noted, discovery "expanded from a useful tool to a combination lawyer's industry and litigator's religion. ${ }^{" 50}$ Before 1938, lawyers who conducted lawsuits were called trial lawyers. After the growth of discovery shifted the focus from trial to expanded pretrial proceedings, trial lawyers began to be called litigators. ${ }^{51}$ For most, "trial lawyer" was no longer an accurate title. Even in the small minority of cases in which trials occurred, ${ }^{52}$ the trials were now often preceded by long periods of intense pretrial maneuvering. ${ }^{53}$ The lawyer's main task was no longer conducting trials. ${ }^{54}$ Instead, the lawyer now focused on pretrial practice, such as filing pretrial motions and conducting discovery. ${ }^{55}$

Because more litigation occurs in state courts than in federal courts, ${ }^{56}$ discovery's impact on the profession was magnified as state after state copied the FRCP in the decades after 1938. Several states acted quickly; by 1948, four states had adopted discovery provisions that mirrored the FRCP. ${ }^{57}$ Eleven more states had virtually copied the FRCP by $1963 .^{58}$ A rush of seventeen additional states joined the parade in the $1960 \mathrm{~s}$ and early $1970 \mathrm{~s} .{ }^{59}$ By the mid-1970s, thirty-three states had discovery rules that mirrored the FRCP ${ }^{60}$ More recently, a few more states joined. ${ }^{61}$ By the mid-1980s, thirty-nine states allowed broad federal-style discovery. ${ }^{62}$

In addition, broad discovery's impact on the profession grew greater as lawyers gradually began to adjust their professional behavior to the new discovery environment. ${ }^{63}$ Even after a jurisdiction adopted wide-open discovery, it could take years for lawyers to learn to exploit fully the opportunities that discovery offered both to obtain information and to seek strategic advantage.

\section{Id. at 2203.}

50. Id.

51. Id.

52. See William A. Glaser, Pretrial Discovery and the Adversary System 97-98 (Russell Sage Found. 1968).

53. See Rosenberg, supra note 48 , at 2203-04.

54. See id.

55. See id.

56. See, e.g., Marc Galanter, News from Nowhere: The Debased Debate on Civil Justice, 71 DENV. U. L. REV. 77, 92 (1993).

57. See John B. Oakley \& Arthur F. Coon, The Federal Rules in State Courts: A Survey of State Court Systems of Civil Procedure, 61 WASH. L. REV. 1367, 1378-1433 (1986) (discussing states' adoption of rules that resembled the FRCP, including discovery provisions).

58. See id. at 1427.

59. See id.

60. See id.

61. See id.

62. See id.

63. Charles W. Sorenson, Jr., Disclosure Under Federal Rule of Civil Procedure 26(a)_ 'Much Ado About Nothing?,' 46 Hastings L.J. 679, 695-96 (1995). 


\section{A Flawed System and Continual Tinkering with the Rules}

Almost immediately after 1938, lawyers and commentators began to note the new system's flaws. ${ }^{64}$ Initially, the focus was on how broad discovery in federal and state litigation caused litigation costs to grow quickly. ${ }^{65}$ Discovery costs soon began to consume more than one-third of the average case's litigation costs. ${ }^{66} \mathrm{In}$ the decade after 1938, testimony before Congress and a cascade of articles criticized the new discovery rules. ${ }^{67}$

Among other concerns, a frequent complaint was discovery's great expense. ${ }^{68}$ For example, in 1951, an official for the federal courts wrote: "Today, after thirteen years of experience under liberal discovery rules, complaints are heard. It is said: (1) That discovery is expensive and time consuming out of proportion to benefits; that depositions last weeks, interrogatories and admissions cover thousands of items, and motions to produce call for tons of documents. $" 69$ Similarly, the report from an extensive 1954 investigation concluded:

[T] he average practitioner, in addition to being saddled with such overhead expenses as rising costs of office rents and clerical help, must cope with increased court costs, filing fees and lengthy pre-trial examinations ... which are generally required in all negligence actions, regardless of the nature of the injury or the amount of the probable recovery. ${ }^{70}$

Likewise, a 1957 article in the ABA Journal on the new pretrial discovery rules noted, "Even though the Rules specifically provide protective measures against abuse, embarrassment and undue annoyance, nevertheless not only our own observations but the reported cases demonstrate the terrific time, expense and effort which can be, and are to a significant extent, the results of the procedure outlined in these Rules." 71

Cost increases that resulted from wide-open discovery were not limited to increases in pretrial costs. In addition, discovery both reduced the frequency of

64. For a list of some of the early articles that criticized discovery, see William H. Speck, The Use of Discovery in United States District Courts, 60 YALE L.J. 1132, 1133 n.3 (1951).

65. See id. at 1132.

66. See GLASER, supra note 52, at 179.

67. See Speck, supra note 64, at 1133 n.3.

68. Id. at 1132 .

69. Id. Another survey described lawyers' common complaints about discovery, one of which was, "Litigation is more expensive and takes more time than formerly, because of the great amount of work and documentation introduced by discovery." GLASER, supra note 52, at 36.

70. Louis P. Contiguglia \& Cornelius E. Sorapure, Jr., Lawyer's Tightrope-Use and Abuse of Fees, 41 CoRnell L.Q. 683, 701 (1956).

71. Clyde A. Armstrong, The Use of Pretrial and Discovery Rules: Expedition and Economy in Federal Civil Cases, 43 AM. B. Ass'N J. 693, 694 (1957). 
settlement and caused trial costs other than discovery to increase. ${ }^{72}$ The drafters of the FRCP had predicted that, although discovery would impose some additional cost before trial, total costs would decline because discovery would cause more cases to settle. ${ }^{73}$

The prediction was wrong. Both earlier and recent studies demonstrate that discovery did not produce a higher proportion of settlements than would occur without discovery. ${ }^{74}$ Instead, at the same time that discovery increased pretrial costs, it decreased the settlement rate, caused trials to become longer, and failed to reduce surprise at trial. ${ }^{75}$ Scholars have developed various theories about why discovery deters settlement; including the explanation that discovery appears to create more disagreements than it resolves. ${ }^{76}$ Moreover, it appears that once litigants have spent large amounts on discovery, litigants have psychological difficulty in letting go and settling, even when it is in their financial interest to do so. ${ }^{71}$

Whatever the reasons, the bar recognized that discovery caused total litigation costs to increase. ${ }^{78}$ The following conclusion from a 1951 American Bar Association ("ABA") survey was typical:

Discovery does not appear to have been successful in speeding the disposition of cases, for instead the courts seem to have taken over a larger share of the burden of investigation. A comparison between cases with and without discovery in Chicago and Maryland disclosed that discovery is associated both with the cases which take longer to dispose of and with cases which more often go to trial. ${ }^{79}$

Likewise, a lawyer from Indiana compared practice in federal court with practice in state court, where discovery was prohibited, and noted, "Our office

72. See GLASER, supra note 52, at 97-98, 101, 107; see also Rosenberg, supra note 48, at 2204; Speck, supra note 64, at 1152, 1155; Changes Ahead in Fed. Pretrial Discovery, 45 F.R.D. 479,489 (1968). For a review of various empirical studies, see Sorenson, supra note 63, at 706-10 (1995).

73. See GlASER, supra note 52, at 9-12; Rosenberg, supra note 48, at 2204-05.

74. See sources cited supra note 72.

75. See sources cited supra note 72 .

76. A survey of discovery practice concluded, "Discovery gives the attacking party more confidence in raising his price for a settlement, but this often has the unintended effect of carrying the case closer to trial." GLASER, supra note 52, at 97. Glaser concluded that discovery leads to new disagreements between the litigants, rather than resolving disagreements. See id. at 91-101; see also generally Rosenberg, supra note 48, at 2204 (arguing discovery raises more new factual issues than it resolves); Shepherd, supra note 47 (noting the discovery rules establish incentives that induce a litigation arms race and deter settlement).

77. Samuel Issacharoff \& George Loewenstein, Unintended Consequences of Mandatory Disclosure, 73 TEX.L. REV. 753, 753 (1995) (recognizing discovery increases pretrial expenses and psychological studies indicate that people decline to settle after they have incurred great expense).

78. See Speck, supra note 64, at 1154-55.

79. Id. at 1155 . 
files for federal cases are from two to three times as thick as those for comparable cases in state courts . . .." Addressing the problems "of the tremendous expense, effort and time which can be required of parties involved in litigation," a law firm partner from Pittsburgh wrote in the ABA Journal in 1957 that "it seems clearly evident that in many respects the procedure provided for in the Rules has aggravated rather than alleviated them." ${ }^{81}$ A decade later, a survey indicated that discovery costs made up between nineteen and thirty-six percent of litigation costs. ${ }^{82}$

The new wide-open discovery substantially increased costs in another way: by increasing uncertainty. ${ }^{83}$ After broad discovery was introduced, a lawyer was much less certain about the time and expense that a case would require to litigate. ${ }^{84}$ Such uncertainty is a real cost. Indeed, the insurance industry is based on peoples' willingness to pay to eliminate such risk.

Although discovery caused litigation costs to increase greatly in some cases, it caused little increase in others. ${ }^{85}$ Large average discovery costs hid wide variation in discovery costs in individual cases. ${ }^{86}$ A survey in 1951 noted many complaints " $[\mathrm{t}]$ hat discovery is expensive and time consuming." ${ }^{177}$ However, the survey also noted the wide variation in discovery amounts. Some cases had voluminous discovery, but some had little. ${ }^{88}$ Indeed, both this 1951 survey and another survey from the same year noted that no discovery occurred in more than half of the cases filed ${ }^{89}$ Likewise, a survey of discovery costs in the early 1960 s showed that average discovery expenses were substantial. ${ }^{90}$ However, the variation among individual cases was broad. Again, some cases had no discovery, in others it was moderate, and in some it was substantial. ${ }^{91}$ A decade later, surveys continued to show that no discovery occurred in more than half of cases and that in cases with discovery, the amount of discovery varied widely. ${ }^{92}$

80. GLASER, supra note 52, at 162.

81. Armstrong, supra note 71 , at 695.

82. Emery G. Lee III \& Thomas E. Willging, Defending the Problem of Cost in Federal Civil Litigation, 60 DuKE L.J.765, 780 (2010).

83. See generally George B. Shepherd, An Empirical Study of the Economics of Pretrial Discovery, 19 INT'L REV. L. \& ECON. 245, 253-55 (1999).

84. See generally id.

85. See Speck, supra note 64, at 1150.

86. See id.

87. Id. at 1132 .

88. See id.

89. See id. at 1134; The Practical Operation of Fed. Discovery, 12 F.R.D. 131, 133 (1952).

90. See GLASER, supra note 52, at 179.

91. See id. at 164-66.

92. See Paul R. Connally et al., Fed. Judicial Ctr., Judicial Controls in the Civil Litigation Process: Discovery 28-29 (1978), available at http://www.fjc.gov/public/ pdf.nsf/lookup/jcclpdis.pdf/\$file/jcclpdis.pdf [http://perma.cc/TWT8-Q33P]; see also Jeffrey J. Mayer, Prescribing Cooperation: The Mandatory Pretrial Disclosure Requirement of Proposed Rules 26 and 37 of the Federal Rules of Civil Procedure, 12 REV. Litig. 77, 87-88 n.19 (1992); 
Thus, at the beginning of a case, it was difficult to determine which cases would generate much discovery work and which cases would generate little or none. At the beginning of a case, the attorneys had only a vague idea of how much discovery would occur in that case. ${ }^{93}$ A litigant would know, in a general way, that several factors tend to influence a case's discovery amount. For example, research has shown that cases with large stakes or many factual issues tend generally to yield more discovery, while cases with small stakes and few factual disagreements tend to yield less discovery. ${ }^{94}$ However, even after considering these predictive factors, substantial uncertainty still remained..$^{95}$ Statistical models suggest that, even after accounting for many possible influences on the amount of discovery in a particular case, great uncertainty still existed about that amount.$^{96}$ Likewise, a report of a 1963 survey on discovery noted that cases with certain characteristics would tend generally to have large amounts of discovery. ${ }^{97}$ However, even after accounting for these characteristics, the survey concluded, "The range in costs is very great in these suits." 98

A major reason for the unpredictability of a litigant's discovery costs was that the costs depended not only on the litigant's own discovery behavior, but also on the adversary's conduct. ${ }^{99}$ The litigant would need to devote time and expense to respond to each of the adversary's discovery requests. More interrogatories from the adversary would require the litigant to incur greater expense to respond to them. Litigants did not limit their responses to answering the adversary's questions and requests. ${ }^{100}$ An empirical study of discovery behavior in 1963 indicates that, in many cases, a litigant would respond to the adversary's discovery in kind. ${ }^{101}$ If the adversary served fifty-three discovery requests on the litigant, then the litigant would tend to serve fifty-three discovery requests on the adversary. ${ }^{102}$ The additional discovery requests that the litigant served would also require time and expense to draft and they would impose additional costs on the adversary.

Linda S. Mullenix, Discovery in Disarray: The Pervasive Myth of Pervasive Discovery Abuse and the Consequences for Unfounded Rulemaking, 46 STAN. L. REV. 1393, 1434-35, 1441-42 (1994).

93. See generally, Shepherd, supra note 83, at 245-46.

94. See GlaSER, supra note 52, at 55-59, 162-81; Shepherd, supra note 83, at 251.

95. See generally Shepherd, supra note 83, at 257-63.

96. Using data from a detailed survey of discovery in 1963, a study created a statistical model that accounted both for fifteen possible influences on a case's discovery amount and for the possible interaction between the litigants' discovery amounts. Although the influences that were explored accounted for some of the variation in cases' discovery amounts, a substantial amount of variation remained. See id. at 257 tbl.2.

97. GLASER, supra note 52, at 176-77.

98. Id. These characteristics include, among others, the existence of patent claims and antitrust claims. $I d$.

99. See Shepherd, supra note 83, at 257 tbl.2.

100. See id. at 246-47.

101. See id.

102. See id. 
The adversary's behavior was highly unpredictable. ${ }^{103}$ Since 1938, commentators have noted that, in some cases, the litigants' discovery behavior is responsible and predictable. ${ }^{104}$ However, in a large number of other cases, at least one litigant conducts abusive or excessive discovery. ${ }^{105}$ For example, a 1963 study concluded that, in approximately half of the cases, litigants would conduct the amount of discovery that their adversaries expected. ${ }^{106}$ However, in the other half of cases, litigants perceived that their adversaries had conducted unnecessary discovery and had embarked on "fishing expeditions." ${ }^{107}$ In approximately fifteen percent of the cases, the litigant believed that the adversary used discovery not merely to fish for facts, but also to harass the litigant. ${ }^{108}$ A 1951 study found that discovery abuse existed, but that its prevalence was uncertain: "Lawyers agreed that discovery devices are used in some cases to harass the other side into a settlement- 'to create an atmosphere for settlement' as one phrased it--but they were unable to estimate the extent of this abuse." 109

What followed over the coming years was continued dissatisfaction with the discovery process interspersed approximately once per decade with modest reform attempts. ${ }^{10}$ Dissatisfaction in the late 1950s and early 1960 s led to funding of a large study of discovery practices in the mid-1960s. ${ }^{111}$ This in turn led to modest amendments in $1970 .{ }^{112}$

After another decade of continued dissatisfaction, additional amendments occurred in 1980 and $1983 .^{113}$ The new changes required additional judicial supervision of discovery. ${ }^{114}$ A discovery conference was now required, signing of discovery requests now certified that they were necessary, and judges were to impose time limits for discovery and stop discovery that was disproportionate. ${ }^{115}$

The changes helped little. ${ }^{116}$ Judges refused or were unable to both police discovery effectively and to make the disproportionality decisions. ${ }^{17}$ The decades since 1938 in which judges had been required to intervene little in

103. See id.

104. See Sorenson, supra note 63, at 706-10.

105. See id. at 701 n.76.

106. See Glaser, supra note 52, at 118-19.

107. See id.

108. See id.

109. Speck, supra note 64 , at 1152.

110. See GLASER, supra note 52, at 26-37.

111. Id.

112. Marcus, supra note 23, at 161.

113. See generally Amendments to the Fed. Rules of Civil Procedure, 85 F.R.D. 521 (1980); Amendments to the Fed. Rules of Civil Procedure, 97 F.R.D. 1675 (1983).

114. See generally Amendments to the Fed. Rules of Civil Procedure, 85 F.R.D. 521 (1980); Amendments to the Fed. Rules of Civil Procedure, 97 F.R.D. 1675 (1983).

115. See generally Amendments to the Fed. Rules of Civil Procedure, 85 F.R.D. 521 (1980); Amendments to the Fed. Rules of Civil Procedure, 97 F.R.D. 1675 (1983).

116. Marcus, supra note 23, at 162-63.

117. Id. 
discovery had created habits that were hard to break. ${ }^{118}$ In addition, judges felt that they lacked sufficient information about cases to decide whether discovery requests were proportionate. ${ }^{119}$ Thus, as Richard Marcus noted, the changes "were something of a dud." 20

After another decade of dissatisfaction, the federal discovery provisions received seemingly important new changes in $1993 .{ }^{121}$ There were numerical limits on depositions, moratoriums on discovery until the parties met and submitted a discovery plan to the judge, and most controversially, mandatory initial disclosures of relevant witnesses and documents. ${ }^{122}$

After additional discontent, especially with mandatory initial disclosure, additional changes occurred in $2000 .{ }^{123}$ The rules limited mandatory disclosure to documents that supported a party's claims or defenses. In addition, the changes narrowed the scope of discovery modestly. ${ }^{124}$

Despite discovery causing lawyers continual irritation, it produced one great benefit for the profession. As will be seen in a later section, discovery has eventually led to increases in lawyers' incomes and the hiring of more lawyers; which occurred once discovery caused the profession to switch to hourly billing in the late 1960s and early 1970s. ${ }^{125}$ The combination of discovery and hourly billing was a bonanza for lawyers.

\section{The Supreme Court Eliminates Discovery in Many Cases}

In two recent decisions, the Supreme Court recognized that the decades of tinkering with the rules had not worked. ${ }^{126}$ Despite all of the rule changes, discovery abuse was still pervasive. So the Supreme Court effectively eliminated discovery in many cases. ${ }^{127}$ It did so not by changing the discovery rules, but by changing the pleading rules to make it much more difficult for a plaintiff to survive a motion to dismiss for failure to state a claim. ${ }^{128}$ For these cases, the decisions effectively eliminated discovery. ${ }^{129}$

In Bell Atlantic Corp. v. Twombly and Ashcroft v. Iqbal, the Supreme Court abandoned the notice-pleading standard that had existed for more than half a

118. Id.

119. Id.

120. Id. at 163 .

121. Amendments to the Fed. Rules of Civil Procedure, 146 F.R.D. 401 (1993).

122. Marcus, supra note 23, at 163-164.

123. Amendments to the Fed. Rules of Civil Procedure, 192 F.R.D. 340 (2000).

124. Carl Tobias, Congress and the 2000 Federal Civil Rules Amendments, 22 CARDOzo L. REV. 75, 80-82 (2001).

125. See infra Part II.A.

126. See generally Ashcroft v. Iqbal, 556 U.S. 662 (2009); Bell Atl. Corp. v. Twombly, 550 U.S. 544 (2007).

127. See generally Iqbal, 556 U.S. 662; Twombly, 550 U.S. 544.

128. See generally Iqbal, 556 U.S. 662; Twombly, 550 U.S. 544.

129. See generally Iqbal, 556 U.S. 662; Twombly, 550 U.S. 544. 
century. ${ }^{130}$ The notice-pleading standard was one of the two columns that supported the system for broad discovery; in many cases, discovery was broad only because the combination of notice-pleading and the discovery rules permitted discovery.

Notice pleading and the discovery rules would combine to produce broad discovery in two steps. First, notice pleading would permit a complaint to survive until the discovery process began. ${ }^{131}$ Until the two decisions, a plaintiff was permitted to file a complaint that provided the defendant with nothing but minimal notice about the nature of the plaintiff's claims against the defendant. ${ }^{132}$ A complaint with few, or no, facts would usually survive a motion to dismiss.

Second, when the motion to dismiss had been surmounted, the plaintiff could move on to conduct discovery. ${ }^{133}$ The broad discovery rules would then become important, permitting the plaintiff to obtain broad categories of information, including, perhaps, the facts that were necessary to support the allegations in the complaint.

In sum, before the decisions, the combination of notice-pleading and the discovery rules meant that a plaintiff whose complaint contained few facts could conduct discovery. Indeed, the system permitted plaintiffs to use discovery to find the facts to support the complaint. As the Court noted in Hickman v. Taylor in 1947, the system that new the FRCP created was designed to permit a plaintiff to file a conclusory complaint now and then find the facts to support the complaint later in discovery. The Court stated, "No longer can the time-honored cry of 'fishing expedition' serve to preclude a party from inquiring into the facts underlying his opponent's case." ${ }^{134}$ The combination of notice pleading and the discovery rules opened the discovery floodgates.

Twombly and Iqbal have now, in many instances, closed these floodgates, eliminating discovery in some cases. No longer are fishing expeditions allowed. The plaintiff must now have facts in hand at the time of filing the complaint. The plaintiff may no longer file the complaint first and then use the discovery process to find facts later.

In the two decisions, the Court made it much more difficult for a plaintiff's complaint to survive a motion to dismiss and therefore much more difficult for a plaintiff to be able to proceed far enough in the case to be permitted to conduct discovery. That is, the decisions' effect is to shut off many plaintiffs from access to the discovery process. The two decisions have, in many cases, eliminated discovery just as effectively as would a revision to the FRCP that eliminated depositions, interrogatories, or requests for production.

The facts of Twombly are simple. The plaintiff alleged that the defendants

130. See generally Iqbal, 556 U.S. 662; Twombly, 550 U.S. 544.

131. See generally Iqbal, 556 U.S. 662; Twombly, 550 U.S. 544.

132. See generally Conley v. Gibson, 355 U.S. 41 (1957); Dioguardi v. Durning, 139 F.2d 774 (2d Cir. 1944).

133. See generally Conley, 355 U.S. 41; Dioguardi, 139 F.2d 774.

134. Hickman v. Taylor, 329 U.S. 495, 507 (1947). 
had conspired to violate antitrust laws. ${ }^{135}$ However, the plaintiff's complaint lacked any direct evidence that the defendants had conspired together ${ }^{136}$ Instead, the plaintiff hoped to acquire such evidence during the case's discovery process. ${ }^{137}$ That is, the case would have been just the sort of "fishing expedition" that the Court in Hickman in 1947 had said was permitted under the system of notice pleading and broad discovery.

The Court's analysis proceeded as follows. First, the court recognized that earlier attempts, noted above, to control and reduce discovery had failed. ${ }^{138}$ For example, the Court wrote that increased judicial supervision of the discovery process was no solution stating:

It is no answer to say that a claim just shy of a plausible entitlement to relief can, if groundless, be weeded out early in the discovery process through "careful case management," given the common lament that the success of judicial supervision in checking discovery abuse has been on the modest side. ${ }^{139}$

Quoting at length from an article by a federal judge that indicated that better judicial case management could not reduce discovery abuse, the Court noted, "Given the system that we have, the hope of effective judicial supervision is slim." "140

Likewise, the Court indicated that discovery abuse could not be eliminated by either increased use of summary judgment or improved jury instructions: ${ }^{141}$ "It is self-evident that the problem of discovery abuse cannot be solved by 'careful scrutiny of evidence at the summary judgment stage,' much less 'lucid instructions to juries." 142

Instead, even with better case management, better summary judgment practice, and improved jury instructions, unscrupulous plaintiffs with frivolous cases could still extort large settlements by threatening to impose discovery expense. The Court noted that, even with the new approaches to control discovery abuse, "the threat of discovery expense will push cost-conscious defendants to settle even anemic cases before reaching those proceedings." ${ }^{143}$

The Court then reached its striking conclusion: to eliminate the possibility of discovery abuse, it was necessary to tighten the pleading standard-here for pleading conspiracy under section 1 one of the Sherman Antitrust Act. ${ }^{144}$ The Court indicated that "it is only by taking care to require allegations that reach the

135. Twombly, 550 U.S. at 544.

136. Id. at 564 .

137. Id. at 559 .

138. Id. at 563 .

139. Id. at 559 .

140. See id. (quoting Easterbrook, supra note 9, at 638-39).

141. Id. at 569-70.

142. Id. at 559 .

143. Id.

144. Id. at 556 . 
level suggesting conspiracy that we can hope to avoid the potentially enormous expense of discovery in cases with no "reasonably founded hope that the [discovery] process will reveal relevant evidence" to support a $\S 1$ claim."145 Cases that failed to achieve this pleading standard would be dismissed and prohibited from continuing on to the next stage where discovery was allowed. ${ }^{146}$ That is, a case would now be dismissed if the only way that a plaintiff could win it is to conduct a discovery fishing expedition.

The later decision in Iqbal made clear that the new pleading standard applied generally and not just to antitrust cases. ${ }^{147}$

Although the opinions in Twombly and Iqbal did not purport to change interpretation of the specific discovery rules, Rule 31 through 36 of the FRCP, they had the same impact in many cases as if the Court had revoked the rules. In many cases in which discovery would have been available before the decisions, discovery is now no longer available; the plaintiff's complaint must now be dismissed before the case reaches the discovery phase.

Twombly and Iqbal represent a fundamental rejection of the discovery system that the FRCP established in 1938 and that the Court had protected for seven decades. Concluding that the existing system created inefficiencies and abuse, and that other judicial and legislative attempts at cures had failed, the Court stopped merely tinkering. Instead, it eliminated discovery for many cases. The decisions represent a fundamental reduction in the number and type of cases in which discovery is available.

The Court did exactly what this Article proposes, except the Court eliminated discovery for only some cases. The only difference between this Article's thesis and what the Court did in Twombly and Iqbal is that this Article suggests that reform should go further and eliminate broad discovery in all cases.

\section{E. Continuing Major Harms}

Despite the continued tinkering at the system's edges and despite the changes from Twombly and Iqbal, the system's fundamental structure remains intact. Just as before, litigants in many cases can demand large amounts of information from their adversaries and impose large costs. Thus discovery still imposes the harms about which lawyers and litigants began to complain immediately after 1938 . Indeed, changing technology, especially information that is now available in electronic form, has caused the harms to worsen. ${ }^{148}$

There are two reasons why the system does not provoke complete outrage. First, lawyers often benefit from discovery because it increases their incomes, although at their clients' expense. Second, the system has existed for so long that most have gotten used to it. Almost nobody is alive who remembers life in the

145. Id. at 559 (quoting Dura Pharm., Inc. v. Broudo, 544 U.S. 336, 347 (2005)).

146. See id. at 569-70.

147. See generally Ashcroft v. Iqbal, 556 U.S. 662 (2009).

148. See generally Ryan J. Reaves, The Dangers of E-Discovery and the New Federal Rules of Civil Procedure, 3 OKLA. J.L. \& TECH. 32 (2007). 
United States without discovery. Familiarity has deadened almost everyone to its obvious flaws.

The following are discovery's impacts. They are mainly harmful. There are two main categories: effects on legal costs and outcomes and effects on legal culture and relationships.

1. Broad Discovery's Impacts on Legal Costs and Outcomes.-Discovery has increased litigation costs. A large study by the Federal Judicial Center examined more than 1000 cases in federal court in case categories that would tend to have at least some discovery. ${ }^{149}$ The results indicate that discovery consumes approximately half of all litigation expenditures for the median case. ${ }^{150}$ Because the sample included some cases that had no discovery, a safe conclusion is that, in cases with discovery, discovery on average imposes more than half of all litigation expenses.

In absolute terms, the amounts that discovery consumes are large. ${ }^{151}$ The study indicated that discovery, in the median case, consumed approximately three percent of the stakes. ${ }^{152}$ That is, in a case with stakes of $\$ 10$ million, direct discovery expense would be more than $\$ 300,000$. Other earlier studies have produced similar estimates as to both relative and absolute expenses for discovery. ${ }^{153}$

These expenses did not include the costs to the client of disruption from discovery. For example, not included were the costs of company employees' identifying responsive documents. Nor did they include the large costs of the disruption when officers, directors, and other employees must be prepared for and attend depositions. Even apart from the direct legal fees for discovery, the discovery process in substantial litigation can paralyze a company. Although discovery's indirect costs are impossible to measure with accuracy, indirect costs may often exceed the direct costs for attorney's fees.

Such costs might be acceptable if they achieved anything beneficial. However, all of the expense and disruption appears to be counterproductive. For example, a major benefit that the drafters promised for the 1938 federal discovery provisions was that discovery would promote quick settlement. ${ }^{154}$ The rules would force each litigant to put his or her cards on the table. ${ }^{155}$ When the litigants could see the relative strengths of their and their adversaries' cases, cases would quickly settle. ${ }^{156}$ Indeed, the new discovery provisions would do much of the work in achieving the "just, speedy, and inexpensive determination

149. See Thomas W. Willging et al., An Empirical Study of Discovery and Disclosure Practice under the 1993 Federal Rule Amendments, 39 B.C. L. REv. 525, 528 (1998).

150. See id. at 531; see also Marcus, supra note 23, at 167.

151. Willging et al., supra note 149 , at 548-49.

152. See id. at 549; Marcus, supra note 23, at 167.

153. See generally GLASER, supra note 52.

154. See Marcus, supra note 23, at 170 n.97.

155. Id.

156. Id. 
of every action," as the drafters promised in their new Rule $1 .{ }^{157}$

The predictions have been wrong. As already mentioned, both earlier and recent studies indicate that rather than increasing the settlement rate, discovery has reduced it. ${ }^{158}$

Because discovery makes the litigation process inefficient and consumes so much additional lawyer time, it has increased lawyers' incomes and led to the hiring of many additional lawyers. ${ }^{159}$ But the high incomes for a large population of lawyers is at society's expense. Incomes and employment would increase in the nuclear power industry, at least in the short run, if the industry purposefully caused a meltdown. Indeed, higher incomes and employment for lawyers is one of discovery's harms, not a benefit. ${ }^{160}$ That lawyers benefit from the waste that discovery causes does not change the fact of the waste.

Moreover, even if one looks only at discovery's impacts on the legal profession - as this Article does in the next section-rather than appropriately on its impact on society as a whole, the other harms that discovery causes more than overwhelm the possible financial benefit that discovery has provided to the profession. The profession, not just society as a whole, is worse off with discovery.

Although discovery is expensive, disruptive, and decreases the settlement rate, it might nonetheless be worthwhile if it produced outcomes with more justice. Occasionally, discovery achieves this goal. ${ }^{161}$ For example, plaintiffs in a products liability case may discover the smoking-gun document that establishes the defendant's liability. ${ }^{162}$ For example in Grimshaw v. Ford, the plaintiff obtained discovery of an internal Ford document that indicated that the company had, in deciding not to install a cheap safety device, balanced the cost of the device against the value of the lives that might be saved. ${ }^{163}$ Likewise, in an U.S. Department of Justice antitrust suit against Microsoft, the government obtained many of Bill Gates's and other executives' internal emails in which they indicated their intention to squash the competition. ${ }^{164}$

However, the discovery process often produces injustice instead. Eventually, plaintiffs started to win cases against tobacco companies in part because of internal company documents - although the documents were often obtained by leaks from employees rather than through the discovery process. ${ }^{165}$ However, a major tool that tobacco companies had successfully used for decades to fend off

157. FED. R. Civ. P. 1.

158. See sources cited supra note 72 .

159. Shepherd \& Cloud, supra note 2, at 135.

160. Id. at 162 .

161. See generally Grimshaw v. Ford Motor Co., 174 Cal. Rptr. 348 (Ct. App. 1981).

162. See generally id.

163. Id. at 800 .

164. Ellen Neuborne, Microsoft's Teflon Bill, Bloomberg (Nov 1998), www.businessweek.com/1998/48/b3606125.htm [http://perma.cc/B482-WKU6].

165. See generally Burton v. R.J. Reynolds Tobacco Co., 170 F.R.D. 481 (D. Kan. 1997). 
tobacco plaintiffs was discovery. ${ }^{166}$ The companies would bury tobacco plaintiffs in intrusive, expensive discovery requests about the plaintiffs' personal history - such as inquiries into plaintiffs' earlier use of illegal drugs-while at the same time resisting the plaintiffs' discovery requests doggedly. ${ }^{167}$

Likewise, defendants in cases involving birth defects and illnesses from birth control devices and drugs used during pregnancy would intimidate plaintiffs with massive discovery requests. ${ }^{168}$ The requests would seek disclosure of plaintiffs' sex histories and other embarrassing information. ${ }^{169}$ The broad scope of discovery would permit intrusion into these areas, even though the information that was sought was barely relevant. Intimidated and outspent in a litigation war of attrition, the plaintiffs would often abandon the cases or settle cheaply. ${ }^{170}$

In many cases, discovery is not a weapon for justice, but for injustice. Indeed, studies show that litigants frequently use discovery not legitimately to obtain necessary information. ${ }^{171}$ Instead, they impose discovery requests strategically to impose costs. ${ }^{172}$ Some cases descend into discovery wars of attrition with each litigant attempting to use discovery requests to exhaust the adversary.

No data exists on the relative sizes of the groups of cases where discovery promotes justice rather than deters it. This author's own experience in litigation, augmented by discussions from many other experienced litigators, is that only rarely does discovery produce the smoking-gun document that makes a difference to a case's outcome. Rarely does such a smoking gun exist. If it does exist, photocopy technology often causes it to exist not only in the defendant's internal files, but also in external sources such as the files of lawyers, accountants, or disgruntled employees. In this way, that document would be available even without discovery.

Discovery's usual impact is to either achieve the same result as would have occurred without discovery with much more trouble and expense, or to distort the result away from justice with just as much trouble and expense. A litigation partner in the large law firm of Debevoise \& Plimpton while discussing foreign legal systems without discovery noted:

There may be a few smoking guns (more likely, water pistols) that are not unearthed, and perhaps even a few truly meritorious suits that do not succeed. But it is extremely doubtful that these few exceptions justify

166. Milo Geyelin \& Ann Davis, Tobacco: A Vast Trove of Tobacco Documents Opens Up-Tobacco Foes Target Role of Lawyers, WAll St. J., Apr. 23, 1998, at B1.

167. Id.

168. Morton Mintz, At Any Cost: Corporate Greed, Women and the Dalkon Shield (Pantheon 1985).

169. Id.

170. Information about defense tactics of defendants mentioned in these paragraphs comes, in part, from the personal experiences of the author.

171. See Shepherd, supra note 83, at 251.

172. Id. 
the overwhelming burdens and abuses wrought by our current system of pretrial practice and discovery. ${ }^{173}$

Indeed, corporations and wealthy people may use the threat of discovery to intimidate potential litigants into refraining even from filing suit. For decades, many potential tobacco plaintiffs would not sue because they foresaw the discovery barrage that the tobaccos companies and their legions of lawyers would throw at them if they did. ${ }^{174}$ Indeed, that was one of the tobacco industry's main tactics: deter additional lawsuits by litigating each one that was filed in the most expensive way possible. ${ }^{175}$ A main way of imposing the expense was through discovery. ${ }^{176}$

Litigants make the decision whether to sue in the shadow of the discovery process. It is certain that many lawsuits with strong merits that would otherwise succeed are never filed because of the discovery process.

Opportunities for litigants to impose costs and intimidate have further increased in the past two decades as discovery of electronic information has begun. ${ }^{177}$ A corporate defendant will fear a request for all of the company's email relating to a certain issue. The review of this mass of material for privilege and relevance would be expensive and time-consuming.

By increasing litigation's costs and the uncertainty of these costs, wide-open discovery has restricted access to legal services for some of society's most vulnerable groups. Both the increase in litigation costs and the increased uncertainty raises the effective price of litigating a case. Those with the least wealth are least able to pay the higher price. By increasing litigation's costs, broad discovery effectively denies these people recourse to lawyers, the courts, and justice.

Moreover, wide-open discovery increases litigation's effective cost most for those who are risk averse and who are thus most sensitive to the risk from discovery. ${ }^{178}$ These tend to be small businesses and individuals with few assets, for whom the risk of an unexpectedly large legal bill is unbearable. ${ }^{179}$ In contrast, large corporations and wealthy individuals tend to be less risk averse. ${ }^{180}$ In this sense, wide-open discovery weights the scales of justice against small businesses and poor individuals and in favor of large corporations and the wealthy. ${ }^{181}$

173. Loren Kieve, Discovery Reform, 77 AM. B. Ass'N J. 79, 81 (1991).

174. See generally Christine Hatfield, The Privilege Doctrines-Are They Just Another Discovery Tool Utilized by the Tobacco Industry to Conceal Damaging Information?, 16 PACE L. REV. 525 (1996).

175. Id. at 558-60.

176. $I d$.

177. Lance Shapiro, E-Discovery: Bargaining Bytes for Settlement, 27 GEO. J. LEGAL ETHICS 887, 887-88 (2014).

178. See Shepherd \& Cloud, supra note 2, at 103-04.

179. Id.

180. Id.

181. Id. 
This is true for both potential plaintiffs and defendants. Discovery's expense and uncertainty prevented some plaintiffs from asserting valid claims. For example, a plaintiff who, before the introduction of wide-open discovery, might have sued his or her landlord for illegally failing to maintain his or her apartment now may be unable to afford to sue. Under hourly billing, the potential plaintiff expects even this small case to require a prohibitive number of expensive hours of attorney time, many for discovery. Moreover, although the case might settle quicker than expected, there is also a substantial possibility that litigation costs would explode and drain the plaintiff's assets. Unable to bear discovery's expense or risk, the potential plaintiff may not assert his or her rights. Similarly, the plaintiff is unable to obtain representation on a contingency or at an affordable fixed fee because discovery has increased both the expected cost and the cost uncertainty that attorneys must cover. So plaintiff's contingency lawyers refuse cases that, absent discovery, they would have accepted. Or if fixed-fee representation is available, its price is prohibitive.

Conversely, the cost and uncertainty of broad discovery prevented some defendants from obtaining representation to defend against invalid claims. Some defendants may settle even invalid claims for substantial sums because the settlement sums are cheaper than the large new costs that discovery imposes.

Defenders of the discovery process proclaim as a main argument in favor of the process that most cases have no discovery. ${ }^{182}$ For example, Stephen Subrin argued:

What neither foreign commentators on American discovery nor homegrown conservative critics tend to mention is the extensive empirical research in our country demonstrating that in many American civil cases, often approaching fifty percent, there is no discovery, and in most of the remainder of the cases there is remarkably little. ${ }^{183}$

That many litigants avoid the discovery process is not evidence that the process functions well. To the contrary, it supports the conclusion that the system functions poorly. If the discovery process were so wonderful, then half of the litigants would not, in effect, choose to opt out of it. Moreover, if discovery were eliminated, these litigants would not miss it at all; indeed, they have taken matters into their own hands and eliminated it in their own cases themselves. That most potential users of discovery avoid it may suggest that something about discovery is very wrong.

Litigants' decision not to use discovery can be explained in two ways, neither of which indicates that the discovery process functions well.

First, some cases may have such small stakes or clear evidence that discovery is not worth its substantial time, expense, and disruption. This is not evidence that the discovery process works well. Instead, it shows that discovery is too expensive, time-consuming, and disruptive for most cases.

182. Stephen N. Subrin, Discovery in Global Perspective: Are We Nuts?, 52 DePaul L. Rev. 299, 308 (2002).

183. Id. at 308 . 
Second, even if a litigant's case has large stakes and important factual disputes, the litigant nonetheless may seek no discovery for fear that doing so will trigger the adversary to impose expensive discovery requests on the litigant. Empirical studies show an important influence on the amount of discovery that a litigant seeks is the amount his or her adversary seeks, regardless of the litigant's real need for information. ${ }^{184}$ A litigant may fear that conducting any discovery will induce the adversary to strike back in kind, triggering an expensive discovery war of attrition. ${ }^{185}$ Experienced lawyers and their clients have seen too many other cases in which discovery and its expense have spun out of control. ${ }^{186}$ Like the United States and Soviet Union with their missiles pointed at each other during the Cold War, an equilibrium results in some cases in which neither party conducts discovery.

This explanation again demonstrates a basic flaw in the discovery process: it can be used not only to obtain information, but also to impose costs and disruption on the adversary. The fact that in many cases these threats balance out to the point that both litigants are intimidated into conducting no discovery shows only that discovery creates a fear of mutual assured destruction, not that the discovery process is a good idea.

Twombly and Iqbal have eliminated some of the harms from discovery. ${ }^{187}$ But they have not eliminated all of them. For example, suppose that a case survives to the discovery phase because the complaint offers sufficient facts to satisfy the new pleading standard. Both the plaintiff and defendant may then seek to gain advantage by conducting abusive discovery. Full elimination of discovery's dangers can be achieved only by eliminating discovery completely.

Moreover, the uneven prohibition of discovery that Twombly and Iqbal imposed is not ideal. The two cases eliminate potentially abusive discovery by plaintiffs in some cases, but not by defendants. It would be better to eliminate broad discovery for all parties evenhandedly.

2. Effects on Legal Culture and Relationships.-Broad discovery not only increases expense and warps case outcomes. It also corrodes both the practice of law and relationships between lawyers and clients.

First, the discovery process is deadeningly boring. It requires both the creation of mountains of paper and tedious attention to detail. It is not much of an overstatement to assert that it has ruined the practice of law. Before discovery came to dominate litigation, the day-to-day activity in litigation was much more fun. ${ }^{188}$ Regardless of their pay, trial lawyers, as they were called then, could enjoy their jobs. ${ }^{189}$ People would become lawyers who were not in it solely for

184. See Shepherd, supra note 83 , at 251.

185. Id.

186. See, e.g., id.

187. See generally Ashcroft v. Iqbal, 556 U.S. 662 (2009); Bell Atl. Corp. v. Twombly, 550 U.S. 544 (2007).

188. See Mary Ann Glendon, A Nation Under Lawyers 20-21 (1st ed. 1994).

189. Id. 
the money. ${ }^{190}$ Many lawyers recall a golden era of litigation that ended, perhaps without coincidence, just as discovery became dominant. ${ }^{191}$

Now, in contrast, discovery has made much of litigation so tedious that many litigators, as they are now called, conclude that the only reason to do it is for the high pay. ${ }^{192}$ In recent decades, lawyers' pay at the top firms has increased at the same time that the lawyers in them have become more miserable. ${ }^{193}$ Associate turnover at the best firms has reached stunning levels, often twenty percent per year. ${ }^{194}$ A typical first-year associate is a smart idealist who has learned all about lawyers' being statesmen in a noble profession. ${ }^{195}$ Often within a year, the associate is crushed into disillusioned depression by the tedious, wasteful reality of big-firm discovery practice. ${ }^{196}$ Contributing to the demoralization is the growing understanding that much of the discovery contributes little to justice and is used to intimidate adversaries or pad legal bills.

The associate may look longingly at friends who work in practices that include little discovery, such as criminal prosecution or criminal defense, smaller-scale litigation with individual clients, or other work for state and local government.

Second, broad discovery injures the relationship between lawyer and client. So-called "principal-agent conflicts" exist and create opportunities for abuse when an agent who has authority to make decisions on a principal's behalf has different incentives than the principal. For example, much waste may exist in the medical profession because doctors often have broad discretion to decide what procedures and medications to use, but insurance companies pay for them. Because of the principal-agent conflicts, insurance companies appear to mistrust doctors.

The discovery process has worsened the principal-agent conflict between lawyers and clients substantially because it provides lawyers with broad new

190. Id. at 22-23.

191. See Marc Galanter \& Thomas Palay, Tournament of Lawyers 32-36 (Univ. of Chi. Press 1991); Glendon, supra note 188, at 17-39; AnTHONy T. Kronman, The Lost LAWYer 29192 (Harvard Univ. Press 1993); William G. Ross, The Honest Hour 5-6 (Carolina Acad. Press 1996). Alternately, it might be that lawyers of any given era always tend to believe that the previous generation of lawyers was more moral. For example, during the 1930s - the supposed golden age - many lawyers proclaimed vigorously that moral standards had fallen precipitously compared to the previous generation. See, e.g., George B. Shepherd \& William G. Shepherd, Scholarly Restraints? ABA Accreditation and Legal Education, 19 CARDOZO L. REV. 2091, $2117-$ 19 (1998).

192. GLENDON, supra note 188 , at 25-26.

193. GALANTER \& PALAY, supra note 191, at 34-36.

194. See Paul Oyer \& Scott Schaefer, What Drives Turnover and Layoffs at Large Law Firms?, GEO. U. (2010), www.law.georgetown.edu/academics/centers-institutes/legalprofession/documents/upload/Conference-Papers-March-23-oyerlayoffs.pdf [http://perma.cc/T7WD-6ZFV].

195. GALANTER \& PALAY, supra note 191, at 36.

196. See id. 
discretion to spend large amounts of their clients' money. Before 1938, there was little that a dishonest trial lawyer could do to pad her bills. ${ }^{197}$ The tasks in a case were relatively set and straightforward. ${ }^{198}$ Moreover, as discussed below, litigators were generally paid fixed fees rather than billing by the hour. ${ }^{199}$

However, broad discovery's introduction gave lawyers broad new opportunities for exploiting their clients. As lawyers began to be paid by the hour, an unscrupulous lawyer could conduct excessive discovery to increase his or her income. A client would have little choice but to accept the lawyer's decision about the appropriate discovery level, even though the client would know that his or her attorney had an incentive and opportunity to cheat. Some attorneys undoubtedly did cheat; some could not resist an open cookie jar.

The result was a new mistrust of lawyers. ${ }^{200}$ The rise of broad discovery occurred at the same time that both the supposed golden age for lawyers ended and public perceptions of lawyers declined. ${ }^{201}$ Indeed, lawyers now rank near the bottom of polls on the public's perceptions of ethical behavior, along with insurance salesmen and car salesmen. ${ }^{202}$ In all of these professions, the individuals must rely on experts for information in situations in which the expert's interests conflict with the interests of the individual. Perhaps absent discovery, lawyers would be perceived more like members of professions for which the public has greater trust. ${ }^{203}$

Third, broad discovery rots relationships among lawyers. Because the amount of discovery to conduct is within each opposing litigant's discretion, a danger exists in every case that the adversary will perceive any discovery request from a litigant as too much. ${ }^{204}$ If the adversary is paying his or her attorney on a contingency, then the expense of responding to the discovery request comes straight out of the attorney's wallet. It is no surprise that surveys show that, in high proportions of cases, at least one litigant believes the adversary is conducting excessive discovery. ${ }^{205}$

Moreover, in addition to creating the possibility of incorrect perceptions of discovery excess, the discovery process creates new opportunities for unscrupulous lawyers actually to oppress their colleagues and gain unfair advantage. ${ }^{206}$ The introduction of discovery into litigation is like the introduction of the machine gun onto the battlefield. In the wrong hands, the new weapon creates many new opportunities for litigation mayhem and destruction.

197. See Ross, supra note 191, at 14-25.

198. Shepard \& Cloud, supra note 2, 120-26.

199. Id.

200. See Honesty/Ethics in Professions, Gallup (Dec. 2014), http://www.gallup.com/ poll/1654/Honesty-Ethics-Professions.aspx?version=print [http://perma.cc/26FP-RFL6].

201. Id.

202. Id.

203. Id.

204. See, e.g., Changes Ahead in Fed. Pretrial Discovery, 45 F.R.D. 479, 489 (1968).

205. Id.

206. $I d$. 
The discovery process functions well only in a system in which all participants cooperate. ${ }^{207}$ It is a bad fit in the United States' adversary system in which everything else assumes and encourages zealous advocacy, the exact opposite of cooperation. ${ }^{208}$

The hurt and mistrust among lawyers that the discovery process creates infects their relationships outside the courtroom. Lawyers now view themselves less as part of a cohesive, proud profession and more as lone gladiators, mistrustful of the knife in the back from a colleague. ${ }^{209}$

Fourth, broad discovery violates norms of privacy. Before 1938, a societal expectation existed that things said or written in privacy would remain private. ${ }^{210}$ The Supreme Court's enforcement of a right to privacy reflects this norm. ${ }^{211}$

The discovery process violates this norm. Many private discussions and written communications are unprivileged and discoverable. ${ }^{212}$ For example, those who have not become deadened to the system - especially foreigners - may often be shocked that a litigant may obtain copies of almost all of a corporation's private emails. ${ }^{213}$ In the Microsoft antitrust case, the government's most powerful evidence was informal internal emails between Microsoft's top leadership. ${ }^{214}$ Likewise discoverable - for example in a divorce proceeding - are the contents of an individual's computer, including the embarrassing websites that the person has visited and love letters that the person has received. ${ }^{215}$

Something important is lost when private individuals may not communicate in private without the constant threat that government agents - and that is what the courts are-will listen in. If everyone were not so accustomed to discovery's intrusiveness, everyone would see more clearly that the discovery process brings the United States frighteningly close to the world in Orwell's $1984 .{ }^{216}$ Only here, Big Brother is a court enforcing an order compelling discovery. ${ }^{217}$

The United States is alone in allowing the courts to intrude in this way into privacy. ${ }^{218}$ For example, European legal systems are motivated much more deeply by an underlying expectation of the privacy of both personal and business information. $^{219}$

207. See generally Mayer, supra note 92 , at 77.

208. Id. at 89 .

209. See GLENDON, supra note 188 , at $36-38$.

210. See generally Amendments to the Fed. Rules of Civil Procedure, 48 F.R.D. 487 (1970).

211. See Hickman v. Taylor, 329 U.S. 495, 511-12 (1947).

212. See, e.g., United States v. Microsoft, Co., 253 F.3d 34, 76 (D.C. Cir. 2001).

213. Id.

214. Id.

215. See, e.g., Byrne v. Byrne, 650 N.Y.S.2d 499, 500 (App. Div. 1996).

216. George Orwell, 1984 (Signet Classic Publ'g 1949).

217. See generally id.

218. See, e.g., Marcus, supra note 23, at 193.

219. Id. at 193-94. 


\section{Discovery Causes Hourly Billing and More Harms}

Both economic theory and historical experience lead to the same conclusion: the legal profession was pushed irresistibly to hourly billing by economic pressures that resulted from wide-open pretrial discovery. By creating unbearable cost uncertainty for lawyers who handled litigation matters, wide-open discovery forced lawyers and, surprisingly their institutional clients, to demand that the traditional forms of fixed fees be abandoned in favor of hourly billing. ${ }^{220}$

After tracing the path by which wide-open discovery caused the change to hourly billing, this Article discusses some of the harms of hourly billing. Because discovery caused hourly billing, these harms stem indirectly from discovery. As will be shown in a later section, elimination of discovery might permit the profession to return to fixed fees, as in other countries.

\section{A. The Path From Discovery to Hourly Billing}

In the middle of this century, imposition in the United States of broad pretrial discovery was followed by the emergence of hourly billing as the primary method of calculating attorney's fees. ${ }^{221}$

As astonishing as it might seem to lawyers who recently entered practice, the standard billing practice has not always been billing by the hour. ${ }^{222}$ Lawyers began to use hourly billing widely only in the last three decades. ${ }^{223}$ Until the mid1960 s, the normal fee contract provided for some form of a fixed fee, whether a monthly or yearly retainer, a fixed fee for a given task, or a contingency fee. ${ }^{224}$

Unlike hourly billing, a contingency fee is a form of fixed fee because it does not change directly with the amount of work that the lawyer does ${ }^{225}$ However, during the 1960s and early 1970s, much of the legal profession switched to hourly billing. ${ }^{226}$ Instead of paying a fixed fee, the client would pay for each hour that the lawyer devoted to the client. ${ }^{227}$

It was not coincidence that hourly billing became dominant after the adoption of rules that encouraged discovery. ${ }^{228}$ These two fundamental changes in the practice of law were linked. ${ }^{22}$ The expansion of discovery in the 1938 Federal Rules, later copied by many of the states, was a substantial factor causing the

220. This brief discussion of the causes of hourly billing builds upon a more complete discussion in Shepherd \& Cloud, supra note 2, at 126-29. See also Ross, supra note 191, at 47.

221. Shepherd \& Cloud, supra note 2, at 126-29.

222. See id. at 94 .

223. $I d$.

224. Id.

225. See id. at 101.

226. The notable exception was contingent fees, which still were used widely by attorneys who represented plaintiffs, particularly in personal injury litigation.

227. Id at 94 .

228. Id. at 95 .

229. Id. 
legal profession to switch from fixed-fee billing to hourly billing for litigation. ${ }^{230}$ Related forces caused the profession also to switch to hourly billing for transactional work. ${ }^{231}$

The system of wide-open discovery pushed the legal profession to embrace hourly billing for litigation because discovery increased uncertainty about litigation costs. ${ }^{232}$ To explore this connection, a brief description is helpful of a theoretical economic model of the conditions under which client and lawyer will choose either fixed-fee or hourly billing. ${ }^{233}$

The model suggests that the optimal contract will be influenced by a balancing of two concerns: efficient risk distribution and limiting 'moral hazard'-moral hazard is the danger that a fixed-fee contract will induce the lawyer to conduct too little work and that an hourly contract will induce excess work. ${ }^{234}$ Economic forces will encourage the client and lawyer to choose the contract type that offers the lowest sum of risk costs and costs from moral hazard. ${ }^{235}$

The historical record suggests that, before the expansion of pretrial discovery, the fixed-fee contract tended to be optimal for litigation matters because its combined costs for risk and moral hazard were lower than those for the hourly contract. ${ }^{236}$ Lawyers for institutional clients provide a useful example. ${ }^{237}$ Because these lawyers tended to be more risk averse than their institutional clients, the fixed-fee contract's shifting of some cost risk to these lawyers was mildly inefficient; the fixed-fee contract required the risk-averse lawyer rather than the more risk-neutral client to absorb unexpected costs. ${ }^{238}$ However, the inefficiency was small because, before the introduction of broad discovery, cost uncertainty was small. ${ }^{239}$ This small inefficiency was more than made up for by the fixed-fee contract's elimination of the moral hazard to conduct excess billing that an hourly contract would have created. ${ }^{240}$

The model shows that if cost uncertainty increases and lawyers are more risk averse than their clients, then it will be efficient for the lawyer and client to switch to hourly billing. ${ }^{241}$ Hourly billing will begin to benefit both the client and the attorney, and both will prefer it and demand it. ${ }^{242}$ As cost uncertainty

230. $I d$.

231. $I d$.

232. Id. (describing notable exceptions to the switch, including contingency fees, which still were used widely by attorneys who represented plaintiffs, particularly in personal injury litigation).

233. Id.; see also id. at 99-119 (presenting a full explanation of the model).

234. Id. at 95 .

235. $I d$.

236. $I d$.

237. Id.

238. Id.

239. Id.

240. Id.

241. Id.

242. Id. 
increases, the lawyer's risk-bearing costs under the fixed-fee contract increase. ${ }^{243}$ If cost uncertainty increases sufficiently, then the risk costs that the fixed-fee contract imposes on the lawyer will eventually exceed the fixed-fee contract's moral-hazard-reducing benefits. ${ }^{244}$ At that point, the lawyer will be better off under hourly billing even after compensating the client for accepting the cost uncertainty and the moral hazard. ${ }^{245}$ After uncertainty increases, the harms that the hourly contract causes by creating an incentive to overbill will be outweighed by the hourly contract's benefits in shifting risk from the risk-averse lawyer to the risk-neutral client. ${ }^{246}$ The client and lawyer will be able to reach an hourly fee agreement such that switching to hourly billing benefits both of them. ${ }^{247}$

Hourly billing will be especially attractive if lawyers tend to be relatively loyal to their clients and relatively resistant to the moral hazard. ${ }^{248}$ In contrast, fixed-fee billing will remain optimal for clients who are more risk averse than their lawyers, such as in many representations of personal-injury plaintiffs. In these relationships, fixed-fee contracts - such as contingency agreements - both allocate risk efficiently and limit moral hazard ${ }^{249}$ Fixed-fee billing will also be optimal for lawyers who, under an hourly contract, would be very disloyal to their clients by billing excessive hours. ${ }^{250}$

The history of billing for legal services confirms the model's predictions. ${ }^{251}$ The adoption of wide-open discovery had two effects. ${ }^{252}$ First, as already seen, wide-open discovery increased uncertainty about a case's litigation costs. ${ }^{253}$ Discovery substantially increased the unpredictability of the amount of legal services that a case would require. ${ }^{254}$ No one would know whether a case would remain quiet or whether it would explode into a long, time-consuming discovery battle. ${ }^{255}$ Because most lawyers had litigated cases under fixed-fee agreements, the increase in cost uncertainty that resulted from wide-open discovery increased lawyers' uncertainty about their incomes. ${ }^{256}$ The increase in cost uncertainty had the same impact on lawyers' happiness as an increase in their costs. ${ }^{257}$

Second, in addition to elevating cost uncertainty, discovery directly increased

243. Id.
244. Id.
245. Id. at $95-96$.
246. Id. at 96.
247. Id.
248. Id.
249. Id.
250. Id.
251. Id.
252. Id.
253. Id.
254. Id.
255. Id.
256. Id.
257. Id.


the expected cost of litigating a case, including the value of the lawyer's time..$^{258}$ The increase in costs contributed to a decline in real incomes for litigators after $1938{ }^{259}$ For some law firms, litigation became an unprofitable loss-leader for transactional work. ${ }^{260}$ Litigators' incomes declined because, at least in part, price stickiness prevented lawyers from increasing their fixed fees quickly enough to match the sharp jump in expenses that resulted from the new discovery regime. ${ }^{261}$

In the mid-1950s, the profession finally reached its breaking point. ${ }^{262}$ The increased uncertainty and decreased incomes finally forced the profession to act. $^{263}$ Litigators, particularly those who represented institutional clients, responded to both problems by switching from fixed-fee billing to hourly billing. ${ }^{264}$ Hourly billing now tended to be optimal for litigators because it efficiently distributed the new cost uncertainty in litigation away from risk-averse lawyers to less risk-averse institutional clients. ${ }^{265}$ For example, according to a lawyer's response to a 1951 survey on discovery, "the possibility of prolonged discovery before trial made him hesitate to accept retainers." ${ }^{266}$ This was "because, although he could reasonably estimate the time required for other aspects of the case, he could not forecast the time required for discovery." ${ }^{267}$ On the other hand, because wide-open discovery had increased uncertainty only for litigation, clients and lawyers initially continued to rely on fixed-fee billing for transactional work. ${ }^{268}$

Confirming the model's prediction that the increased uncertainty from discovery would cause hourly billing to benefit both clients and lawyers, many clients began to demand the change to hourly billing. ${ }^{269}$ Even when faced with the possibility that hourly billing would cause lawyers to pad their bills, clients decided that it was cheaper for the client to pay the lawyer by the hour than to pay the large risk premium that the lawyer would require to take the case on a fixed fee. ${ }^{270}$

The organized bar offered an additional purported reason for shifting to

258. Id.

259. $I d$.

260. $I d$.

261. Id.

262. Id.

263. Id. The lag between the initial adoption of the FRCP and the switch to hourly billing occurred for three reasons: the profession felt discovery's full force only after state courts mimicked federal courts and also began to offer broad discovery; lawyers learned to exploit discovery only after several years of experience with it; and the inertia of the profession's many years of fixed-fee billing deterred a quick move to hourly billing. $I d$.

264. Id. at 96-97.

265. Id. at 97.

266. Id. (quoting Speck, supra note 64, at 1152).

267. Id.

268. Id.

269. Id.

270. Id. 
hourly billing. ${ }^{271}$ In response to lawyers' declining incomes - to which the introduction of broad discovery had contributed - the American Bar Association and other lawyers' organizations mounted campaigns in the late 1950s to urge lawyers to switch to hourly billing because of the bar's prediction that hourly billing increased lawyers' incomes. ${ }^{272}$ The prediction seemed to come true. ${ }^{273}$ Beginning in the mid-1960s, lawyers experienced a large increase in income. ${ }^{274}$ Many lawyers believed that hourly billing deserved credit for the increase. ${ }^{275}$

However, other factors were probably more important contributors to the increase in lawyers' incomes. ${ }^{276}$ For example, in the 1960 s, soon after the widespread switch to hourly billing began, society's rules and regulations were suddenly becoming more complicated. ${ }^{277}$ Lawyers' incomes increased in part because society's new complexity made lawyers' services more valuable. ${ }^{278}$

In addition, and perhaps most importantly, the existence of the discovery process increased the time, risk, and therefore the cost of litigation. ${ }^{279}$ Eventually, this led to substantial increases in lawyers' incomes. ${ }^{280}$ In a competitive market, compensation must eventually cover producers' costs or producers will stop production.

The model suggests that instead of increasing legal fees, hourly billing actually may have limited the increase. ${ }^{281}$ This helps explain why clients demanded hourly billing and have continued to demand it: hourly billing benefited clients. ${ }^{282}$

In the 1960 s, cost uncertainty also began to increase for transactional work. ${ }^{283}$ Just as broadened discovery had earlier increased cost uncertainty for litigators, increasing complexity in society and the legal system began to increase cost uncertainty for transactional lawyers. ${ }^{284}$ As the model predicts, transactional lawyers and their clients then also switched to hourly billing. ${ }^{285}$ By 1978 , except for contingency representations, the profession had moved to hourly billing for most private-sector legal services. ${ }^{286}$

The theoretical model also helps to explain why many lawyers continue to

271. Id.
272. Id.
273. Id.
274. Id.
275. Id.
276. Id.
277. Id.
278. Id. at $95-97$.
279. Id. at 96.
280. Id. at 97.
281. Id. at $97-98$.
282. Id. at 98.
283. Id.
284. Id.
285. Id.
286. Id.


litigate personal injury cases under contingency agreements, a fixed-fee variant. ${ }^{287}$ An increase in uncertainty makes hourly billing optimal only if the client is less risk averse than the lawyer. ${ }^{288}$ Unlike most institutional clients, many personal injury plaintiffs are more risk averse than their lawyers. ${ }^{289}$

\section{B. Hourly Billing's Harms}

Like the discovery process, hourly billing has harmed the profession in many ways. Commentary on hourly billing's harms is profuse, with a common summary being that hourly billing has ruined the practice of law. ${ }^{290}$

Confronting these harms, the ABA established its Commission on Billable Hours. ${ }^{291}$ The preface to commission's report, written by the ABA's president, provides a good summary of hourly billing's impacts:

It has become increasingly clear that many of the legal profession's contemporary woes intersect at the billable hour. . . Today, unintended consequences of the billable hours model have permeated the profession. A recent study by the ABA shows that many young attorneys are leaving the profession due to a lack of balance in their lives. The unending drive for billable hours has had a negative effect not only on family and personal relationships, but on the public service role that lawyers traditionally have played in society. The elimination of discretionary time has taken a toll on pro bono work and our profession's ability to be involved in our communities. At the same time, professional development, workplace stimulation, mentoring and lawyer/client relationships have all suffered as a result of billable hour pressures.

The profession is paying the price. Disaffection with the practice of law is illustrated by a feeling of frustration and isolation on the part of newer lawyers who, due to time-billing pressures, are not being as well mentored as in the past. Time pressures also result in less willingness on the part of lawyers to be collegial, which only exacerbates work load since it necessitates that everything be put in writing. Not coincidentally, public respect for lawyers has been waning since the 1970s. ${ }^{292}$

Because hourly billing ties a law firm's income directly to how many hours its lawyers work, pressures naturally develop for the firm to require its lawyers to work more hours. This is regardless of how productive they are during those

287. $I d$.

288. Id.

289. Id. at 97-98. In addition, the contingency agreement permits the lawyer in effect to loan litigation funding to a client who would otherwise lack sufficient resources to litigate. See id. at 124.

290. See, e.g., GLENDON, supra note 192, at 31-32; Ross, supra note 191, at 229-36.

291. See generally HiRSHON, supra note 6.

292. Id. at ix. 
hours. If lawyers were paid by the page, firms would require more pages. If they were paid by the comma, lawyers would fill their pages with commas.

The ABA report then lists, in much more restrained language than many other commentators, some of the major harms from hourly billing that have combined to create the ABA's sense of crisis. ${ }^{293}$ The list is a good example of many other lists of hourly billing's flaws. This Article now presents the harms that the ABA mentions in italics, interspersed with commentary:

1. "Results in a decline of the collegiality of law firm culture and an increase in associate departures. ${ }^{294}$-Focus on increasing billable hours leads to a frenetic pace at law firms, which leaves little time for collegiality. High-paid but overworked associates regret their deal with the devil and quit.

2. "Discourages taking on pro bono work." 295 _Focus on maximizing billable hours causes firms and associates to avoid non-billable pro bono.

3. "Does not encourage project or case planning." ${ }^{296}$ _Planning is not rewarded because lawyers get paid by the hour regardless of efficiency.

4. "Provides no predictability of cost for the client." 297 -As discussed above, hourly billing shifts cost risk from the lawyer to the client.

5. "May not reflect value to the client." 298 - Hourly billing measures the lawyer's compensation by the time spent on the client's case, not on the value provided to the client.

6. "Penalizes the efficient and productive lawyer." 299 - The lawyer who serves the client quickly and efficiently is paid less than the lawyer who wastes time.

7. "Discourages communication between lawyer and client." 300 —Clients do not call their lawyer because they do not want to pay for the lawyer's time during the call.

8. "Fails to discourage excessive layering and duplication of effort." "301_Firms have an incentive to place as many associates and paralegals on a case as the client will tolerate.

9. "Fails to promote a risk/benefit analysis. "302_-Because lawyers are paid for their work regardless of the work's benefits, hourly billing does not force lawyers carefully to weigh the costs and benefits of the tasks that they perform. Instead, they have an incentive to perform tasks that have no benefits to the client, or even harm him or her.

\footnotetext{
293. Id. at 5

294. Id.

295. Id.

296. Id.

297. Id. at 6 .

298. Id.

299. Id.

300. Id.

301. Id.

302. Id.
} 
10. "Does not reward the lawyer for productive use of technology." lawyer has no incentive to use labor-saving technology. Technology that reduces work for lawyers reduces the lawyers' pay.

11. "Puts client's interests in conflict with lawyer's interests." client's interest is usually to resolve a matter quickly and efficiently. Hourly billing creates the opposite incentive for the lawyer: to resolve the matter slowly and inefficiently.

12. "Client runs the risk of paying for: The lawyer's incompetency or inefficiency." ${ }^{305}$-At least in the short run, inefficient lawyers are paid more than efficient ones. In the long run, the client may fire the inefficient lawyer if the client has sufficient information to detect the inefficiency. However, because the lawyer is the expert, the client may lack sufficient expertise to detect wasteful lawyering.

13. "Client runs the risk of paying for: Associate training." 306 - The firm may get away with billing for associate training.

14. "Client runs the risk of paying for: Associate turnover. ${ }^{307}$-When an associate leaves the firm, the client may end up paying for the time necessary for a new associate to get up to speed.

15. "Client runs the risk of paying for: Padding of timesheets. ",308_An everpresent incentive exists for both lawyers and partners to lie to clients about the number of hours that they spend on the clients' matters. Studies indicate that such dishonesty may be pervasive. ${ }^{309}$ Indeed, partners at law firms have an incentive to encourage associates to inflate hours.

Perhaps paradoxically, the harms from hourly billing are often most severe during the discovery process. Hourly billing creates an incentive for lawyers to conduct excessive discovery. A discovery war of attrition may ruin the client, but it will be a bonanza for the lawyers. Indeed, studies show that lawyers conduct more discovery when they are paid by the hour, rather than under a fixed fee such as a contingency fee. ${ }^{310}$

\section{ENDING THE FAILED EXPERIMENT}

As seen in this Article, broad discovery has by itself inflicted substantial injuries on society and the legal profession, with very few benefits. Moreover, broad discovery has required the profession to adopt hourly billing, which has itself also damaged the profession. The cure is clear: remove the discovery

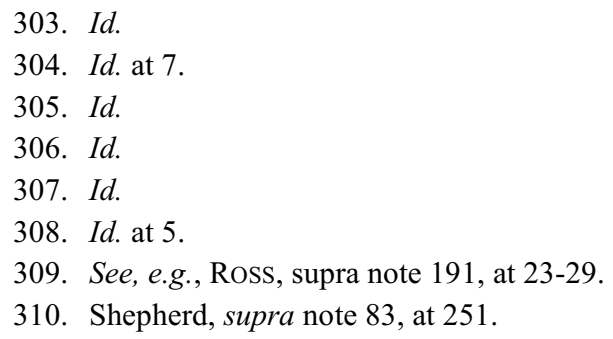


cancer. ${ }^{311}$ The cure would be appropriate and necessary even if discovery did not also cause hourly billing. Because broad discovery and hourly billing are linked, the cure is even more essential.

The world would be a better place without broad discovery. Indeed, the absence of broad discovery has already improved conditions in all other parts of the world except the United States; wide-open discovery exists only here. ${ }^{312}$ The United States should respect the combined and consistent judgment of every other country that broad discovery is bad policy. Confronted with strong evidence of discovery's harms, the United States should cease asserting that it knows better than everyone else.

Although it would be best to eliminate U.S.-style broad discovery, strictlylimited discovery might appropriately remain available in exceptional circumstances. For example, the United States might model reforms on the present systems in Britain, Europe, or Japan. ${ }^{313}$ In these systems, litigants may sometimes obtain limited discovery after convincing a judge of exceptional need. ${ }^{314}$ Often, discovery that takes place is conducted by the judge, not by the litigants. ${ }^{315}$ The modest variations in the world's countries with limited discovery provide a perfect natural experiment for selecting the best approach. Recommending the details of the best new system is a topic for future research.

One might fear that individual plaintiffs suing large organizations would be unable to obtain the secret internal documents that would be necessary to prove liability. However, in general, broad discovery harms the individual litigant rather than helping him. As already discussed, cases where discovery produces a smoking gun are rare. It is probable that more often, discovery is now used as a weapon by the large organizations to gain unfair advantage over the individual litigant.

Moreover, the problem of secret internal documents may be reduced, if not eliminated, by altering burdens of proof. For example, Germany and many other countries impose strict liability on defendants in most product liability suits. ${ }^{316}$

311. A brief earlier essay also called for elimination of broad discovery. Kieve, supra note 173. Other scholars have contrasted the U.S. discovery process with that in other countries, but not called for its elimination. See, e.g., Subrin, supra note 182.

312. See Marcus, supra note 23, at 154-55.

313. For a description of these systems, see generally Burkhard Bastuck \& Burkard Gopfert, Admission and Presentation of Evidence in Germany, 16 LOY. L.A. INT'L \& COMP. L.J. 609 (1994); Benjamin Kaplan et al., Phases of German Civil Procedure I, 71 HARV. L. REv. 1193 (1958); John H. Langbein, The German Advantage in Civil Procedure, 52 U. CHI. L. REv. 823 (1985); Marcus, supra note 23; Itsuko Mori, The Difference Between U.S. Discovery and Japanese Taking of Evidence, 23 INT'L LAW. 3 (1989); Subrin, supra note 182; Craig P. Wagnild, Civil Law Discovery in Japan: A comparison of Japanese and U.S. Methods of Evidence Collection in Civil Litigation, 3 Asian-PaC. L. \& Pol'y J. 1 (2002).

314. See generally sources cited supra note 313.

315. See generally sources cited supra note 313.

316. See Mathias Reimann, Liability for Defective Products at the Beginning of the TwentyFirst Century: Emergence of a Worldwide Standard?, 51 Aм. J. CoMP. L. 751, 764 (2003); Hans 
In suits where a negligence rule still applies, many countries' courts do not require the plaintiff to prove the defendant's negligence. ${ }^{317}$ Instead, they shift the burden of proof to the defendant to rebut a presumption of fault. ${ }^{318}$ Unless the defendant successfully carries the burden, the plaintiff wins the suit, but without requiring discovery. ${ }^{319}$ Moreover, there is no opportunity for the defendant to use discovery to intimidate.

Burdens could be shifted similarly in other areas in which defendants might have sole access to important evidence. For example, in a suit for fraud against a large organization, the U.S. system requires the plaintiff to produce evidence that the defendant knew of a statement's falsity. Before Twombly and Iqbal, the plaintiff could attempt to obtain such information through discovery of the defendant's internal documents. An alternative would be to shift the burden of proof: once the plaintiff proves falsity, the defendant has the burden to prove the absence of knowledge of falsity.

One need not speculate about whether eliminating broad discovery would function well. The system proposed in this Article already works well in scores of other countries. As Professor Subrin has noted about many U.S. commentators' skepticism about various aspects of the U.S. discovery system, "This skepticism has to be heightened when one looks at civil discovery in the rest of the world, where civilizations seemed to have survived quite well without American discovery." 320

Indeed, admittedly inexact bottom-line indicators of legal systems' relative effectiveness suggest that systems without broad discovery perform no worse than, and perhaps better than, the U.S. system. For example, one important underlying goal of a liability system is to deter injurious conduct. ${ }^{321}$ Even without broad discovery, the German system appears to compare favorably with the U.S. system. The automobile accidental death rate in Germany is less than half the U.S. rate. ${ }^{322}$ Although this data ignores other important influences on death rates, it suggests that the absence of broad discovery in Germany is not inducing Germans and German automobile manufacturers to run amok in creating dangerous automobiles.

The elimination of broad discovery would also permit many clients and lawyers to abandon both hourly billing and to avoid all of the problems that it causes. This Article already showed that broad discovery caused hourly billing to become necessary. ${ }^{323}$ If broad discovery were eliminated, then a substantial portion of litigation might revert to forms of fixed-fee billing. During the last few

Claudius Taschner, Harmonization of Product Liability Law in the European Community, 34 TEX. INT'L L.J. 21, 25-27 (1999).

317. See Reimann, supra note 316, at 790-91; Taschner, supra note 316, at 27-28.

318. See Reimann, supra note 316, at 790-91; Taschner, supra note 316, at 27-28.

319. See Reimann, supra note 316, at 790-91; Taschner, supra note 316, at 27-28.

320. Subrin, supra note 182, at 301.

321. See generally Taschner, supra note 258.

322. See, e.g., World Health OrG., supra note 18, at 116, 227.

323. See Shepherd \& Cloud, supra note 2, at 126-29. 
decades, some lawyers and clients have experimented with various forms of fixed-fee billing. ${ }^{324}$ This Article's model suggests that the cause may be because law firms have become large enough to accept additional risk; the model indicates that hourly billing is efficient only when lawyers are more risk-averse than their clients. However, fixed-fee billing has not been widely adopted both because of inertia and because of continuing cost uncertainty in litigation, much of it from discovery.

Broad discovery's elimination and the accompanying elimination of much cost uncertainty might well be the push needed to propel the profession back to fixed fees, at least for litigation. In countries without broad discovery, much more litigation is conducted under fixed fees. ${ }^{325}$ For example in Germany, hourly billing has begun to make inroads, partly due to the influence of German offices of U.S. law firms that use hourly billing. ${ }^{326}$ However, unlike in the United States, much litigation proceeds under fixed-fee schedules. ${ }^{327}$

Elimination of broad discovery might require modest changes in other parts of the legal system. As others have noted, other parts of the system are premised on the existence of broad discovery. ${ }^{328}$ For example, because the U.S. system of notice pleading often requires little detail in plaintiffs' complaints, an important means for defendants to learn of plaintiffs' specific assertions is through discovery. Thus, the elimination of discovery might need to be accompanied by a requirement of greater specificity in pleadings. This would not be a new or unfamiliar requirement. Instead it would merely extend to all cases the present requirements of FRCP 9(b) that fraud be pled with particularity.

One might also need to hire more judges. A possible objection to eliminating broad discovery is that it would place excessive reliance on judges to gather information - if rules were also changed to permit judges, instead of litigants, to conduct more fact-finding, as in many legal European systems. ${ }^{329}$ Unlike European judges, the argument goes, U.S. judges are unaccustomed and unfit to administer the gathering of information. ${ }^{330}$ Moreover, they are often already overwhelmed by heavy caseloads, especially their criminal dockets. ${ }^{331}$ This problem might be solved by hiring more judges.

324. See, e.g., Margaret C. Fisk, Corporate Firms Try Contingency, NAT'L.L.J., Oct. 27, 1997, at A1; see generally Richard C. Reed, Beyond the Billable Hour, An Anthology of Alternative Billing Methods (Am. Bar Ass'n 1989); see also Jill S. Chanen, Constructing

Team Spirit, 83 Aм. B. Ass'N J., 58, 59 (Aug. 1997).

325. See generally Fisk, supra note 325.

326. See Virginia G. Maurer et al., Attorney Fee Arrangements: The U.S. and Western European Perspectives, 19 Nw. J. INT'L L. \& Bus. 272, 320 (1999).

327. Id. at 321.

328. See, e.g., Marcus, supra note 23, at 156; Subrin, supra note 182, at 308-10; see generally Geoffrey C. Hazard, Discovery and the Role of the Judge in Civil Law Jurisdictions, 73 Notre DAME L. ReV. 1017 (1998).

329. See generally sources cited supra note 313.

330. Hazard, supra note 270, at 1021.

331. See Marcus, supra note 23, at 187. 
However, even if the U.S. hired no new judges and the existing judges remained resistant to administering discovery closely, the system would merely suffer from many of the same problems as European courts. European judges also tend to be lazy in their fact gathering. ${ }^{332}$ Instead, European courts demonstrate "a considerable degree of tolerance - almost insouciance, to common law eyes - for the incompleteness of evidentiary material." 333

Instead, European systems rely on litigants to assemble their own information from their own sources, rather than relying on the adversary for information. ${ }^{334}$ In situations where only the adversary often has information, the systems tend to shift the burden to the adversary, rather than requiring the adversary to produce information. ${ }^{335}$

A final impact of the elimination of broad discovery would be that many litigators would lose their jobs. The cuts would be especially great in big firms, where the cases that spawn profuse discovery are litigated.

It is possible that this may already be happening after Twombly and Iqbal. The two decisions have caused some cases to be dismissed and others not to be filed in the first place. ${ }^{336}$ Both developments reduce the need for plaintiffs' lawyers and defense lawyers. It may be that the reduction in legal employment over recent years was due not only to the general recession that the economy suffered. In addition, Twombly and Iqbal may have contributed to the decline in employment for both plaintiffs' and defense lawyers by reducing both the number of cases that are filed and the amount of discovery that is conducted.

The reduction in employment would be a good development. Some of society's smartest, hardest-working people would switch from lives devoted to counterproductive, wasteful discovery to other productive, helpful careers. That the legal profession in many other countries is smaller helps, not harms, these countries.

\section{Conclusion}

The provisions for broad discovery in the 1938 FRCP were a revolutionary experiment. The experiment began to fail from the beginning and has continued to fail. It has dramatically increased litigation's cost and pain, with few balancing benefits. Moreover, it has caused the profession to switch to hourly billing, causing an additional array of harms.

332. See id. at 193.

333. Id. (citing Mirjan R. Damaska, The Uncertain Fate of Evidentiary Transplants: AngloAmerican and Continental Experiments, 45 AM. J. CoMP. L. 839, 843 (1997)).

334. See generally Subrin, supra note 182.

335. See generally id.

336. See generally Ashcroft v. Iqbal, 556 U.S. 662 (2009); Bell Atl. Corp. v. Twombly, 550 U.S. 544 (2007). It is a natural conclusion that these cases, which tightened pleading standards, caused cases to be dismissed and others not to be filed at all. 
Broad discovery should be eliminated, returning the United States to the sensible approach of the rest of the world. The Supreme Court's decisions in Twombly and Iqbal correctly focus on the dangers of discovery abuse and they appropriately require dismissal of some cases that would otherwise become fishing expeditions. But reform beyond this is needed. Broad discovery should be eliminated for all cases. 